\title{
Sembur Karo: Karo's Traditional Medicine as Burns Injury Alternative Treatment with Rattus norvegicus as Model
}

\section{Hennisa1, Novia Risa1, Juliany², Shawn Kelvin², Tyas Delilla Kalati ${ }^{2}$, Raden Rara Endang Lukitaningsih², and Juris Burlakovs ${ }^{3}$}

${ }^{1}$ Faculty of Biology, Universitas Gadjah Mada, Jl. Teknika Selatan, Sekip Utara, Sleman 55000, Indonesia

${ }^{2}$ Faculty of Pharmacy, Universitas Gadjah Mada, Sekip Utara, Sleman 55000, Indonesia

${ }^{3}$ Departement of Biology and Environmental Science, Faculty of Health and Life Sciences, Linnaeus University, SE-391 82 Kalmar, Sweden, European Union

\section{Abstract}

Burns injury can be caused by flame, heat, chemical and electricity and it remains as one of the most serious problems in the medical world. Burns injury can be treated with traditional medicine. One of them is Sembur Karo. The objective of this research was to investigate the Sembur Karo potency for burns injury treatment. Sembur Karo obtained from North Sumatera was identified its plant composition and analyzed for bioactive compounds; flavonoid, steroid, and tannin. Twenty five rats (Rattus norvegicus) were used. The rats were divided into five groups of five.

Corresponding Author: Raden Rara Endang Lukitaningsih

lukitaningsih_end@yahoo.com

Received: 11 February 2017

Accepted: 08 March 2017

Published: 26 March 2017

Publishing services provided by Knowledge $\mathrm{B}$

(c) Hennisa et al. This article is distributed under the terms of the Creative Commons

Attribution License, which permits unrestricted use and redistribution provided that the original author and source are credited.

Selection and Peer-review under the responsibility of the ICBS Conference Committee.

G OPEN ACCESS The first group used as a control without treatment, the second group are sprayed with Sembur Karo, while the third and the fourth groups were applied with Sembur Karo added with water and human saliva respectively. The last group were treated with Bioplacentone. All treatments were done once a day for 3 wk. Each week, one rat from all group were sacrificed with skins were taken for histology specimen. From this research, it was concluded that bioactive compounds in Sembur Karo were isoquersetin, sterol, and condensed tannin. The skin histology showed that the group which sprayed with Sembur Karo had the most effective effect among all groups.

Keywords: burn injury; burn injury recovery; Sembur Karo.

\section{Introduction}

One of the most common injuries around us are burns injury. These types of injury can be category as minor injury which can heal in a few days and serious injury which cannot heal completely. Based on depth of tissues damage, burns injury is divided into burns injury first degree, second degree, and third degree [1].

Around $11 \times 10^{6}$ people in the world who sustain burns injury will seek medical treatment and approximately 300 ooo people die from burn injury every year. The recovery from burn injury is closely related to the size of the injury and age of the person who 
suffered it [2]. Nowadays, people usually use synthetic medicines which are sold in the market, even though there is alternative medicine like herbal or traditional medicine.

While in Indonesia has many types of traditional medicine, it is still rarely used in daily life. Therefore, researchers conducted a number of studies of using traditional medicine from plant for medical treatment including burn injury. Several studies show the herbal traditional medicine can be used to heal the wound for mild-to-moderate burns, such as Aloe vero L. and Hippophoe rhamnoides L. [3, 4].

One of the traditional medicine in Indonesia is Sembur Karo. Sembur Karo is a traditional medicine from Karo tribe in North Sumatra. This medicine is formulated from a variety of seeds and spices. The uniqueness of this medicine is the way to used it by chewing and then spit it into the necessary part of body. It can also be used by brewing it in hot water and drunk it. The Karo tribe is still using this medicine until now as their primary medicine for abdominal pain, colds, and gastric pain. For women who are having menstruation period can used it to reduce abdominal pain. Sembur Karo has many prescription which depend on the illness or wound. In this study, the Sembur Karo which was chosen has the healing agent for burns injury. The purpose for this study is to investigate the potential of Sembur Karo as traditional medicine for burns injury and to determine it can be used as an alternative medicine for burn injury treatment

\section{Material and Method}

\subsection{Plant identification}

Part of the plants was documented overall and its transverse section, while the seeds are collected. Identification was using Flora of Java $[5,6]$ and compared them with the plant photos and seeds.

\subsection{Phytochemical screening}

\subsubsection{Flavonoid}

Ethanol p.a of $5 \mathrm{~mL}$ were added to $2 \mathrm{~g}$ of Sembur Koro and heated in waterbath for 15 min. After that, filtered with filter paper. Filtrate then evaporated with waterbath until the volume reach $1 \mathrm{~mL}$. Mobile phase consisted of ethyl acetate : $n$-hexane $(4: 1)$ and put in a close chamber for $10 \mathrm{~min}$ to fill it. Filtrate of $5 \mu \mathrm{L}$ and quersetin were spotted on the plate. Then, put the TLC plate in the chambers and let the mobile phase eluted. When the mobile phase reached $8 \mathrm{~cm}$, picked the plate up and observed in visible light, UV light at $254 \mathrm{~nm}$ and $366 \mathrm{~nm}$ and used Liebermann-Burchard reagent. Compared the Rf with quersetin. 


\subsubsection{Steroid}

The steroid examination method was the same as flavonoid examination, except ethyl acetate : n-hexane $(7: 3)$ was used as mobile phase. This steroid examination didn't use the reference compound, so the result is compared to the literature.

\subsubsection{Tannin}

The tannin examination method was the same as flavonoid examination, but toluene : acetone : formic acid ( $5: 4: 1)$ were used as mobile phase. Gallic acid was used as reference compound.

\subsection{Animal testing}

\subsubsection{Animal acclimation}

The rats were adapted to the shed for one week in Pharmacology Laboratory. There were 25 rats were used in this research and divided into five groups which were control group (group 1), sprayed with Sembur Karo group (group 2), Sembur Karo mixed with water group (group 3), Sembur Karo mixed with human saliva group (group 4), and Bioplacentone group (group 5).

\subsubsection{Treatment}

All groups were given the second degree burns. Before the burns injuries were given, the hairs on the back of all rats were shaved. Then ketamine was injected through intramuscular route as anesthesia. Burns injuries were induced with round-headed solder with $2 \mathrm{~cm}$ diameter. Solder was heated for $10 \mathrm{~min}$ and affixed to the rats back for $20 \mathrm{sec}$. As for the control group, the burns injuries were left to heal itself, while Bioplacentone group was treated with Bioplacentone gel.

After that, observed the changing of burns injuries diameter visually. The burns injuries recovered if the diameter were fully closed. The time needed for the burns injuries to fully recover also counted for each group and made histology preparation to saw the tissue condition after the burns. Every $7 \mathrm{~d}$, one rat from each group were euthanized to get the burns injury skins [7]. Thereafter, the skins were stored in formalin. The histology preparations for the skin were made in Anatomy Laboratory of Veterinary Medicine, Universitas Gadjah Mada. 


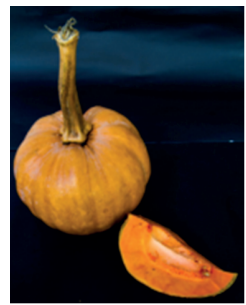

(a)

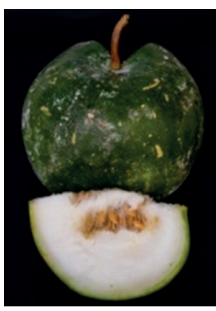

(b)

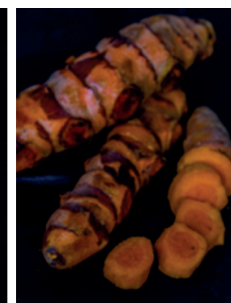

(c)

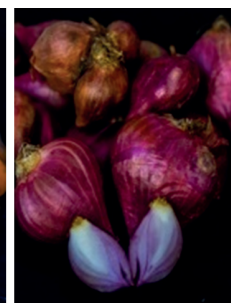

(d)

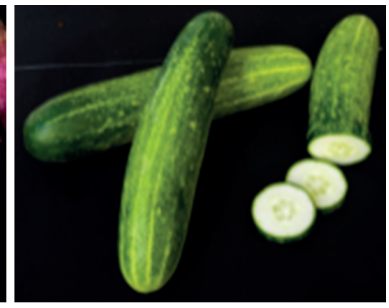

(e)

Figure 1: (a) Cucurbita moschata (Duch.) Poir., (b) Benincasa hispida (Thunb.) Cogn., (c) Languas galangal (L.) Stuntz, (d) Allium cepa L. Syn. Allium ascalonicum L. (Back.), (e) Cucumis sativus L.

\begin{tabular}{l|c|c|c|} 
Compound Sample's Rf & Reference's Rf & \multicolumn{1}{c}{ Group } \\
\hline Flavonoid & 0.69 & 0.81 & Isoquercetin \\
\hline Steroid & 0.50 & - & Sterol \\
\hline Tannin & 0.94 & 0.50 & Condensed tannin
\end{tabular}

TABLE 1: Chromatography analysis.

\section{Results and discussions}

\subsection{Plants identification}

See Figure 1.

\subsection{Phytochemical screening}

See Table 1.

\subsection{Burns injury skin's appearance}

As we could see from the Figure 2, burns injuries were starting to close and turn into reddish color. Also, the recovery time which was needed for this and group was faster compared to the other groups.

\subsection{Histology analysis}

Parts of the plant usually use in Sembur Karo are plant seed and bulb. From the result (Figure 1) of the identification, it was known the parts of the plants in this prescribtion were seeds of Cucurbita moschata (Duch.) Poir with labu kuning as local name, seeds of Benincasa hispida (Thunb.) Cogn. with labu air or gundur as local name, bulbs of Languas galangal (L.) Stuntz which was called lengkuas, bulbs of Allium cepa L. Syn. Allium ascalonicum L. (Back.) with the local name as bawang merah, seeds of Cucumis 


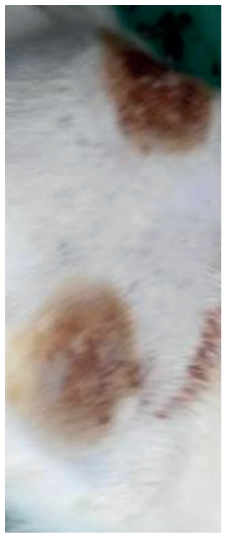

(a)

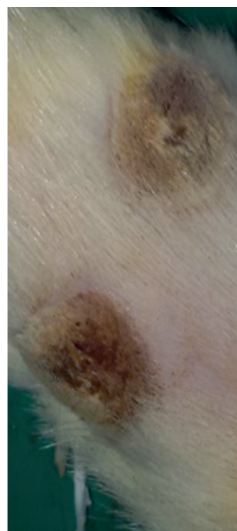

(b)

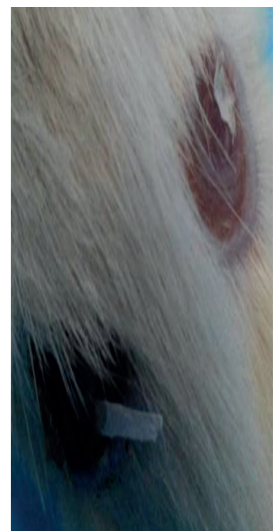

(c)

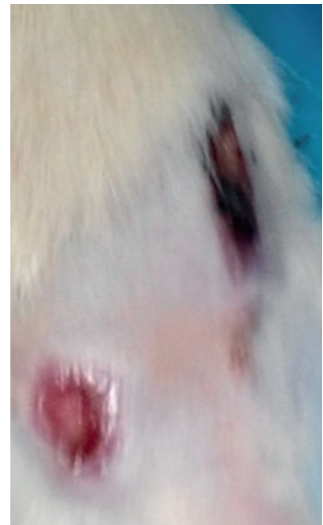

(d)

Figure 2: (a) Burns injuries appearance o $d$ on of the rats from group 2, (b) Burns injuries appearance 7 $\mathrm{d}$ on of the rats from group 2, (c) Burns injuries appearance $14 \mathrm{~d}$ on of the rats from group 2, (d) Burns injuries appearance $21 \mathrm{~d}$ on of the rats from group 2.

\begin{tabular}{|c|c|c|c|c|c|c|c|}
\hline Group & Cellular Inflamation & Haemorraghe & Fibroblast & Collagen & Necrosis & Epitelitation & Result \\
\hline 1 & 4 & 0 & 3 & 2 & 2 & 4 & 3 \\
\hline 2 & 2 & 0 & 1 & 3 & 0 & 3 & 3 \\
\hline 3 & 3 & 0 & 3 & 2 & 2 & 4 & 3 \\
\hline 4 & 2 & 0 & 1 & 1 & 3 & 3 & 2 \\
\hline 5 & 3 & 0 & 2 & 1 & 2 & 3 & 2 \\
\hline
\end{tabular}

sativus L. and the local name is mentimun. The Sembur Karo was made and packed in North Sumatra by the factory.

Result of chromatography analysis (Table 1) indicated that Sembur Karo contains isoquercetin, sterol, and condensed tannin which can act in recovery of burns injury. Isoquercetin from flavonols can act as anti-inflammation agent with decreasing the rate of COX-2 expression in injury cells and inflammatory cell exudation [8]. Sterol can stimulate the macrophages and fibroblasts activity, increasing collagen and proteoglycan synthesis. Those can help in forming new skin layer [9]. While condensed tannin has a role as antimicrobial agent. It can inhibit the growth of microbes such as fungi, yeasts, bacteria, and viruses. So, condensed tannin can prevent further infection by microbes [10].

On the $7 \mathrm{~d}, 14 \mathrm{~d}$ and 21d, the histology preparates were made as one of the recovery parameter. The preparates were analyzed with semi-quantitative (histology scoring) technique and painted with Hematoxylin and Eosine (HE). The analyzed factors were cellular inflamation, haemorraghe, fibroblast, collagen, necrosis, and epitelitation. If fibroblast's score is low and epitelitation, collagen are high, therefore the recovery is considered good. 
From the result (Table 2), the 1st, 2nd, and 3rd groups showed better recovery degree than the other groups. The different between those groups only at necrosis score from the 1st and 3rd group are higher than the 2nd group while the 2nd group has higher collagen score along with lower inflammation degree. Therefore, the recovery at the 2nd group are better than the 1st and 3rd groups, because the probability of leaving scar is very low. It's probably caused by teeth chewing which is turn Sembur Karo into bolus so it improve the surface area and enzyme in saliva works better.

\section{Conclusions}

Sembur Karo is one of traditional medicine from Karo tribe in North Sumatra, Indonesia which is used for primary medicine in Karo tribe. From the study, we suspected that Sembur Karo which used by sprayed had better recovery degree because the effect from chewing and enzymes in mouth. The studies reported in this paper will serve as platform for establishing the therapeutic activity of Sembur Karo. In order to gain more detail about the use of Sembur Karo in burns injury treatment, this research should be conducted further in future.

\section{Acknowledgements}

This study is part of PKM-PE funded by DIKTI and supported by Dirmawa Universitas Gadjah Mada. The authors would like to thank Raden Rara Endang Lukitaningsih and Retno Murwanti as research advisor, Purnomo, in helping the authors identified plants and Sukarti Moeljopawiro as abstract reviewer.

\section{References}

[1] NC. Devi, S. Aminah, and H. Taufikurahman, "Ecological aspects of vaccinium varingiaefolium growing in a stressed volcanic environment," in Presented in Botany Conference, Pp. 34-35, Bandung, ITB, 2001.

[2] M. Heads, "Ericaceae in Malesia: vicariance biogeography, terrane tectonics and ecology," Telopea, vol. 10, no. 1, pp. 311-449, 2003.

[3] B. Hidayat Estiti, Anatomy tumbuhan berbiji [Anatomy of seed plant], ITB Press, Bandung, 1997, 4253 in Bahasa Indonesia.

[4] Gembong. Tjitrosoepomo, "Morfologi tumbuhan: cetakan ke-17 [Plant Morphology]," Yogyakarto: UGM Press, pp. 4-251, 2007, in Bahasa Indonesia.

[5] A. Sadili, R. Kartawinata, A. Kartonegoro, H. Soedjito, and A. Sumadijaya, "Floristic composition and structure of subalpine summit habitats on MT. Gede-Pangrango Complex, Cibodas Biosphere Reserve," in Sumadijaya A. Floristic composition and 
structure of subalpine summit habitats on MT. Gede-Pangrango Complex, vol. 12, pp. 391-404, Indonesia. Reinwardtia, West Java, 2008.

[6] ER. Sakdiyah and RA. Kodir, Studi awal kandungan antosianin pada buah cantigi ungu (Vaccinium varingiaefolium (BL.) MIQ.) yang berpotensi sebagai suplemen antioksidan Preliminary studies on the anthocyanin content Cantigi purple fruit (Vaccinium varingiaefolium (BL.) Miq.) Potential as an antioxidant supplement. Prosiding SnaPP 2012: Sains, Teknologi dan Kesehatan 2012; 3: 95-100 in Bahasa Indoensia.

[7] E. Susetyoadi Kartini, M. Saptasari, and Sulisetijono., "Anatomi tumbuhan [Plant anatomy]," in Anatomi tumbuhan [Plant anatomy], p. 41, UM Press, Malang, 2005, in Bahasa Indonesia.

[8] SA. Suryani and D. Ratnawati, "Stomate response and transpiration rate of Vaccinium varingiaefolium (BI.) Miq. leaf according to leaf development levels and distance ranges from sulphur gases source Sikidang cauldron Dieng Plateau," Yogyakarta: MIPA UNY, pp. 1-12, 2003.

[9] D. Sastramiharja and A. Siregar, "Fisiologi Tumbuhan [Plant physiology]," in Fisiologi Tumbuhan [Plant physiology], p. 34, Departemen Pendidikan dan Kebudayaan, Jakarta, 1996, in Bahasa Indonesia.

[10] W. Prawiranata, S. Harran, and P. Tjondronegoro, "Dasar-dasar fisiologi tumbuhan," jilid 1 [Basic of plant physiology, vol. volume 1], p. 138, 1991, in Bahasa Indonesia.

[11] M. Jovančević, J. Balijagić, N. Menkovič et al., "Analysis of phenolic compounds in wild populations of bilberry (Vaccinium myrtillus L.) from montenegro," Journal of Medicinal Plants Research, vol. 5, no. 6, pp. 910-914, 2011.

[12] W. Chu, S. Cheung, R. Lau, and I. Benzie, "Bilberry (Vaccinium myrtillus L.)," in Herbal Medicine, vol. 20115386 of Oxidative Stress and Disease, Pp. 55-71, CRC Press, , 2011. 